\title{
PENGARUH KINERJA KEUANGAN TERHADAP RETURN SAHAM DENGAN NILAI TUKAR (KURS) SEBAGAI VARIABEL MODERASI
}

\author{
Istiqomah $^{\mathbf{1}}$; Mardiana ${ }^{2}$ \\ Universitas Islam Negeri Maulana Malik Ibrahim Malang ${ }^{1,2}$
}

Email korespondensi: new.isty30@gmail.com ${ }^{1}$; mardiana@uin-malang.ac.id ${ }^{2}$

\begin{abstract}
The purpose of this study was to determine the effect of liquidity ratios $(C R)$, leverage ratios $(D E R)$ and profitability ratios (ROA) on stock returns with exchange rates (exchange rates) as a moderating variable on pharmaceutical subsector companies listed on the Indonesia Stock Exchange for the period 2013-2017. This type of research is quantitative research using secondary data. The method of collecting data from this research is documentation. The sample in this study were 7 companies listed on the Indonesia Stock Exchange in the period 2013-2017 using purposive sampling. This study uses the classical assumption test analysis method, F test, T test and the Moderated Regression Analysis (MRA) Test to test the data examined. The results of this test indicate that liquidity, leverage and profitability have an influence on stock returns simultaneously. Partial testing shows that liquidity and profitability have a positive and significant effect on stock returns, but leverage has a negative and significant effect on stock returns. Whereas in the MRA test, it shows that the exchange rate (exchange rate) is not able to moderate liquidity, leverage and profitability on stock returns.
\end{abstract}

Keywords: Liquidity, Leverage, Profitability, Exchange Rate, Stock Returns

\section{A. PENDAHULUAN}

Perkembangan sektor industri di suatu negara sangat berpengaruh terhadap kemajuan ekonomi negara tesebut, sehingga secara langsung ataupun tidak langung perkembangan pembangunan juga semakin pesat dari waktu ke waktu. Sektor farmasi memiliki peran dalam perkembangan ekonomi dibidang kesehatan. Dalam permasalahan kesehatan yang terjadi pada umumnya sangat berkaitan dengan ketersediaan obat-obatan yang dibutuhkan oleh masyarakat. Indonesia bisa menjadi pasar farmasi yang paling menjanjikan dibanding negara lain di kawasan Asia Tenggara.

Kegiatan investasi merupakan suatu kegiatan menanamkan dana pada satu atau lebih asset selama periode tertentu. Hal ini dilakukan dengan harapan dapat memperoleh pengembalian atau peningkatan atas nilai investasi awal (modal) dan yang bertujuan untuk memaksimalkan hasil (return) yang diharapkan. Berkaitan dengan pemilihan untuk melakukan investasi, menurut Ang (1997) dalam Nidianti (2013) terdapat dua faktor yang mempengaruhi return suatu investasi yaitu yang pertama faktor internal dan faktor eksternal.

Faktor internal perusahaan dapat dilihat dengan menggunakan analisis fundamental. Pada penelitian ini penulis lebih memfokuskan pendekatan fundamental dengan bantuan 
analisis rasio keuangan. Rasio keuangan yang digunakan dalam membantu menganalisis fundamental dalam penelitian ini adalah rasio likuiditas yang diwakili oleh Current Ratio, rasio leverage yang diwakili Debt to Equity Ratio dan rasio profitabilitas yang diwakili Return on Asset.

Pentingnya aspek likuiditas dapat dilihat dengan memperhitungkan dampak yang berasal dari ketidakmampuan perusahaan memenuhi kewajiban jangka pendeknya. Rendahnya likuiditas dapat menghalangi suatu perusahaan untuk memperoleh keuntungan atau kesempatan mendapatkan keuntungan. Hal penting lainnya adalah menyangkut aspek profitabilitas yang merupakan suatu alat untuk memprediksi laba perusahaan karena menggambarkan hubungan antara laba dan jumlah modal yang ditanamkan. Pentingnya aspek leverage salah satunya adalah untuk mengukur atau menilai berapa bagian dari setiap rupiah modal sendiri yang dijadikan jaminan utang jangka panjang.

Investor dapat terbantu dengan adanya rasio keuangan yang memberikan tolak ukur untuk mengambil keputusan dalam berinvestasi agar investasi tersebut memperoleh keuntungan. Rasio keuangan diharapkan dapat memprediksi return saham karena rasio keuangan merupakan perbandingan antar akun dalam laporan keuangan.

Selain faktor internal faktor penentu return saham lainnya adalah faktor dari luar perusahaan atau biasa disebut faktor eksternal. Faktor eksternal yang diperkirakan oleh para ahli bisnis farmasi sebagai penyebab turunnya return saham di sektor farmasi adalah fluktuasi nilai tukar (kurs) rupiah terhadap dolar. Menurut Pujawati, dkk (2015) nilai tukar atau kurs adalah perbandingan antara harga mata uang suatu negara dengan mata uang negara lain.

Menurut Menteri Perindustrian Airlangga Hartarto menyebut, bahwa fluktuasi nilai tukar (kurs) rupiah terhadap dolar sangat berpengaruh terhadap perusahaan farmasi karena pasar obat generik dan bahan baku obat mentah yang 90\% masih impor mengalami kenaikan quantity/kuantitas. Hal tersebut berdampak kepada konsumsi obat yang semakin menurun karena bahan-bahan baku yang lebih banyak didapat impor, membuat produk obat-obatan di Indonesia harganya melambung tinggi (www. kompas.com).

Nilai tukar (kurs) rupiah diindikasikan mempengaruhi return saham dimana menurut Afiyati \& Topowijono (2018) menyatakan bahwa nilai tukar (kurs) rupiah terhadap dolar tentunya akan berpengaruh kepada besarnya keuntungan yang akan didapatkan oleh perusahaan. Terlebih adanya indikasi bahwa nilai tukar (kurs) rupiah terhadap dolar menjadi tolak ukur dari variabel yang dapat digunakan sebagai pengukur return saham. 
Nilai tukar (kurs) dapat mempengaruhi besar kecilnya return saham. Ketika kurs rupiah merosot, jumlah utang perusahaan dan biaya produksi menjadi bertambah besar jika dinilai dengan rupiah. Jika hutang bertambah besar maka tingkat pembayaran pun semakin tinggi dan beresiko sebab hutang yang tinggi memiliki tingkat likuiditas yang rendah. Tentu saja hal ini akan berdampak pada stabilitas perusahaan terutama dalam kemampuan menghasilkan keuntungan.

Penelitian ini bertujuan untuk mengetahui pengaruh likuiditas, leverage dan profitabilitas terhadap return saham pada perusahaan farmasi yang terdaftar di Bursa Efek Indonesia periode 2013-2017 secara parsial dan simultan. Selain itu, juga untuk mengetahui besarnnya pengaruh nilai tukar (kurs) dalam memoderasi kinerja keuangan terhadap return saham pada perusahaan farmasi yang terdaftar di Bursa Efek Indonesia periode 2013-2017

\section{B. TELAAH PUSTAKA}

\section{Kinerja Keuangan}

Menurut Fahmi (2012) kinerja keuangan adalah suatu analisis yang dilakukan untuk melihat sejauh mana suatu perusahaan telah melaksanakan dengan menggunakan aturanaturan pelaksanaan keuangan secara baik dan benar. Dalam melihat suatu kinerja keuangan, terdapat suatu alat ukur yang biasa disebut sebagai rasio keuangan. Rasio keuangan merupakan alat ukur yang digunakan perusahaan untuk menganalisis laporan keuangan. Menurut Fahmi (2014), bagi investor ada 3 rasio keuangan yang paling dominan yang dijadikan rujukan untuk melihat kondisi kinerja suatu perusahaan yaitu rasio likuiditas, rasio sovabilitas dan rasio profitabilitas.

\section{Rasio Likuiditas}

Rasio likuiditas mengukur kemampuan perusahaan dalam memenuhi kewajiban jangka pendeknya. Current Ratio menurut Hanafi (2015) menyatakan bahwa rasio lancar atau (Current Ratio) merupakan rasio untuk mengukur kemampuan perusahaan membayar kewajiban jangka pendek atau utang yang segera jatuh tempo dengan menggunakan aktiva lancar.

Current Ratio (CR) akan dihitung dengan menggunakan rumus sebagai berikut:

$$
\mathrm{CR}=\frac{\text { Aktiva Lancar }}{\text { Utang Lancar }}
$$

(Hanafi, 2015) 


\section{Rasio Solvabilitas / Rasio Leverage}

Salah satu aspek yang dinilai dalam mengukur kinerja perusahaan adalah aspek leverage atau utang perusahaan. Debt to Equity Ratio merupakan rasio yang digunakan untuk menilai hutang dengan ekuitas. Rasio ini digunakan untuk mengetahui jumlah dana (jaminan) yang disediakan untuk peminjam (kreditor) oleh pemilik perusahaan (Fahmi 2014). Debt to Equity Ratio (DER) akan dihitung dengan menggunakan rumus sebagai berikut:

$$
D E R=\frac{\text { Total Hutang }}{\text { Total Equitas }}
$$

(Murhadi, 2013)

\section{Rasio Profitabilitas}

Rasio Profitabilitas bermanfaat untuk menunjukkan keberhasilan perusahaan di dalam menghasilkan keuntungan. Return on Asset (ROA) merupakan salah satu rasio profitabilitas yang penting digunakan untuk mengetahui sejauh mana kemampuan aktiva yang dimiliki perusahaan bisa menghasilkan laba (Hanafi 2015). Return on Asset (ROA) akan dihitung dengan menggunakan rumus sebagai berikut:

$$
R O A=\frac{\text { Laba Bersih }}{\text { Total Asset }}
$$

(Hanafi, 2015)

\section{Return Saham}

Rasio Profitabilitas bermanfaat untuk menunjukkan keberhasilan perusahaan di dalam menghasilkan keuntungan. Return on Asset (ROA) merupakan salah satu rasio profitabilitas yang penting digunakan untuk mengetahui sejauh mana kemampuan aktiva yang dimiliki perusahaan bisa menghasilkan laba (Hanafi 2015). Return on Asset (ROA) akan dihitung dengan menggunakan rumus sebagai berikut:

$$
R=\frac{P_{t}-P_{t-1}}{P_{t-1}}
$$

(Hartono, 2014)

Keterangan

$\mathrm{R} \quad$ : return saham periode $\mathrm{t}$

Pt : harga saham pada periode $\mathrm{t}$

Pt-1 : harga saham pada periode t-1 


\section{Nilai Tukar (Kurs)}

Menurut Mahyus Ekananda (2014) kurs merupakan harga suatu mata uang relatif terhadap mata uang negara lain. Kurs memainkan peranan penting dalam keputusankeputusan pembelanjaan. Hal ini dikarenakan kurs memungkinkan kita menerjemahkan harga-harga dari berbagai negara ke dalam satu bahasa yang sama. Nilai tukar (kurs) akan dihitung dengan menggunakan rumus sebagai berikut:

$$
\text { Kurs Tengah }=\frac{K b+K j}{2}
$$

(Mahyus Ekananda 2014)

Keterangan:

$\mathrm{Kb} \quad$ : kurs beli

$\mathrm{Kj} \quad$ : kurs jual

\section{Kerangka Pemikiran Teoritis}

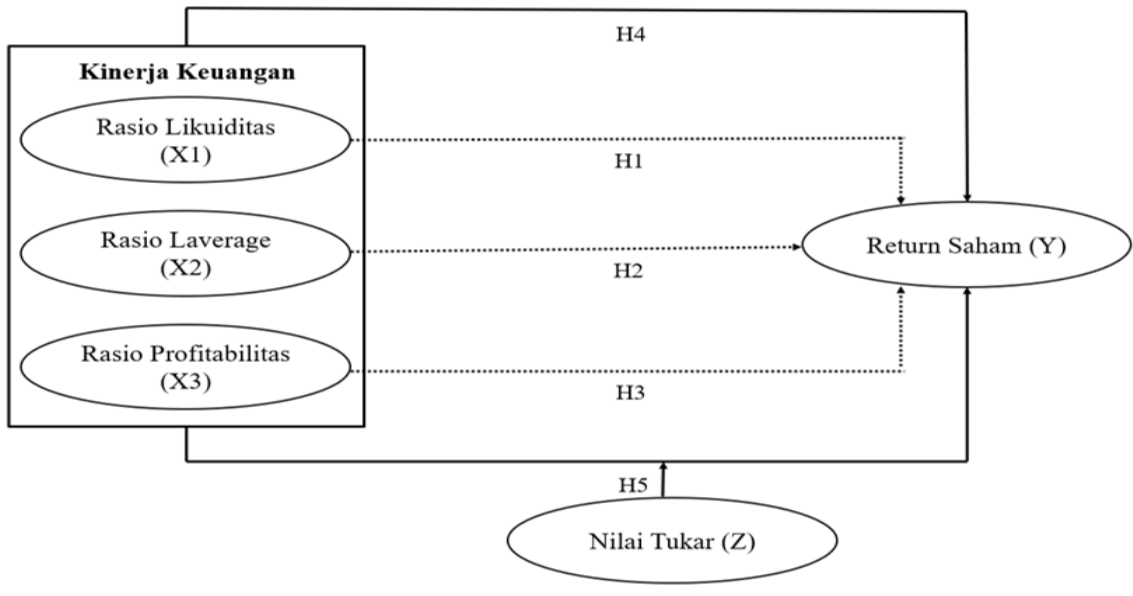

Gambar 1: Model Penelitian

Sumber: Data diolah oleh peneliti (2019)

\section{Hipotesis Penelitian}

$\mathrm{H}_{1} \quad$ : Rasio likuiditas berpenngaruh terhadap return saham

$\mathrm{H}_{2} \quad$ : Rasio leverage berpengaruh terhadap return saham

$\mathrm{H}_{3} \quad$ : Rasio profitabilitas berpengaruh terhadap return saham

$\mathrm{H}_{4} \quad$ : Kinerja keuangan memiliki pengaruh simultan terhadap return saham

$\mathrm{H}_{5} \quad$ : Nilai tukar (kurs) dapat memoderasi pengaruh kinerja keuangan terhadap return saham 


\section{METODOLOGI PENELITIAN}

Jenis penelitian yang digunakan dalam penelitian ini adalah jenis penelitian kuantitatif dimana data yang digunakan merupakan data sekunder. Populasi yang digunakan dalam penelitian ini adalah perusahaan-perusahaan yang terdaftar di BEI dan bergerak di sub sektor farmasi. Populasi dalam penelitian ini berjumlah 10 perusahaan. Sampel penelitian dipilih dengan menggunakan pendekatan purposive sampling. Kriteria yang digunakan dalam teknik pengambilan sampel yaitu:

1. Perusahaan yang akan diteliti adalah perusahaan sub sektor farmasi terdaftar dalam

Bursa Efek Indonesia selama periode 2013-2017.

2. Perusahaan yang mengalami keuntungan setiap tahunnya

Diperoleh sampel sebanyak 8 perusahaan yang terdaftar dalam Bursa Efek Indonesia selama tahun 2013 sampai tahun 2017. Penelitian ini dilakukan dengan menggunakan 3 variable, yakni variabel terikat (dependent variable) adalah return saham, variabel bebas (independent variable) kinerja keuangan, sedangkan variable moderasinya nilai tukar (kurs). Teknik analisis data yang digunakan pada penelitian ini menggunakan uji asumsi klasik, uji regresi, uji MRA, dan selanjutnya dilakukan pengujian hipotesis.

\section{HASIL DAN PEMBAHASAN}

\section{Uji Asumsi Klasik}

Hasil uji asumsi klasik berupa Uji Normalitas menunjukkan nilai signifikansi $0,802>\alpha$ $(0,05)$ maka sesuai dapat disimpulkan bahwa model regresi memenuhi asumsi normalitas. Hasil Uji Multikolonieritas diketahui bahwa nilai tolerance lebih kecil dari 0,10 dan nilai VIF tidak lebih dari 10,00. Hal ini menunjukkan bahwa tidak adanya interaksi yang kuat antar variabel independen, artinya tidak terjadi multikolinieritas. Hasil Uji Heteroskedastisitas diketahui bahwa masing-masing variabel independen diperoleh nilai sig>0,05 maka disimpulkan tidak terjadi heteroskedastisitas atau dengan kata lain asumsi tidak terjadi heteroskedastisitas telah terpenuhi. Hasil Uji Autokorelasi nilai Durbin-Watson mendekati dan di sekitar angka 2 yang berarti asusmsi tidak terjadinya autokorelasi terpenuhi.

\section{Regresi Linier Berganda}

Berdasarkan hasil analisis tabel diatas diperoleh nilai $F$ hitung sebesar 5,607. Nilai ini lebih besar dari F tabel $(5,607>2,911)$ dan nilai sig. F (0,003) lebih kecil dari $\alpha(0,05)$. Hal ini menunjukkan bahwa variabel likuiditas yang diukur dengan $\mathrm{CR}(\mathrm{X} 1)$, leverage yang diukur 
dengan DER (X2) dan profitabilitas yang diukur dengan ROA (X3) secara simultan memiliki pengaruh yang signifikan terhadap return saham.

Tabel 1. Uji Simultan (F) Variabel IndependenTerhadap Variabel Dependen

\begin{tabular}{|l|r|r|r|r|r|}
\hline Model & Sum of Squares & Df & Mean Square & F & Sig. \\
\hline $1 \quad$ Regression & 11,310 & 3 & 3,770 & 5,607 &, $003^{\text {b }}$ \\
Residual & 20,842 & 31 &, 672 & & \\
Total & 32,152 & 34 & & & \\
\hline
\end{tabular}

a. Dependent Variable: Return saham (y)

b. Predictors: (Constant), ROA, DER, CR

Sumber: Hasil Output SPSS 25, data diolah peneliti (2019)

\section{Uji Parsial (T)}

Tabel 2. Uji Parsial (T) Variabel Independen Terhadap Variabel Dependen

\begin{tabular}{|c|c|c|c|c|c|c|}
\hline \multicolumn{7}{|c|}{ Coefficients $^{a}$} \\
\hline \multirow{2}{*}{\multicolumn{2}{|c|}{ Model }} & \multicolumn{2}{|c|}{$\begin{array}{c}\text { Unstandardized } \\
\text { Coefficients }\end{array}$} & \multirow{2}{*}{$\begin{array}{c}\text { Standardized } \\
\text { Coefficients } \\
\text { Beta }\end{array}$} & \multirow[b]{2}{*}{$\mathrm{t}$} & \multirow[b]{2}{*}{ Sig. } \\
\hline & & $\mathrm{B}$ & Std. Error & & & \\
\hline \multirow[t]{4}{*}{1} & (Constant) &,- 324 & 6,81 & &,- 476 &, 637 \\
\hline & CR & ,476 & ,143 &, 502 & 3,333 & ,002 \\
\hline & DER & $-2,069$ &, 746 &,- 435 & $-2,773$ & ,009 \\
\hline & ROA & 4,006 & 1,334 & ,463 & 3,003 & ,005 \\
\hline
\end{tabular}

a. Dependent Variable: Return saham (y)

Sumber: Hasil Output SPSS 25, data diolah peneliti (2019)

Dari hasil Uij T pada tabel 2, dapat disimpulkan sebagai berikut:

1. Rasio likuiditas (CR) berpengaruh positif dan signifikan terhadap return saham. Hal ini terlihat dari $\mathrm{T}_{\text {hitung }}$ yang lebih besar dari $\mathrm{T}_{\text {tabel }}(3,333>2,0395)$ dan juga nilai signifkansi yang lebih kecil dari $\alpha(0,002<0,05)$ maka $\mathrm{H}_{1}$ diterima.

2. Rasio leverage (DER) berpengaruh negatif dan signifikan terhadap return saham. Hal ini terlihat dari $\mathrm{T}_{\text {hitung }}$ yang lebih kecil dari $\mathrm{T}_{\text {tabel }}(-2,773<2,0395)$ dan juga nilai signifkansi yang lebih kecil dari $\alpha(0,009<0,05)$ maka $\mathrm{H}_{2}$ diterima.

3. Rasio profitabilitas (ROA) berpengaruh positif dan signifikan terhadap return saham. Hal ini terlihat dari $\mathrm{T}_{\text {hitung }}$ yang lebih besar dari $\mathrm{T}_{\text {tabel }}(3,003>2,0395)$ dan juga nilai signifkansi yang lebih kecil dari $\alpha(0,005<0,05)$ maka $\mathrm{H}_{3}$ diterima.

Tabel 3. Hasil Uji Determinasi Variabel Independen Terhadap Variabel Dependen

\begin{tabular}{|c|c|c|c|c|}
\hline \multicolumn{5}{|c|}{ Model Summary } \\
\hline Model & $\mathrm{R}$ & R Square & $\begin{array}{c}\text { Adjusted R } \\
\text { Square }\end{array}$ & $\begin{array}{l}\text { Std. Error of the } \\
\text { Estimate }\end{array}$ \\
\hline 1 &, $693^{\mathrm{a}}$ & ,481 & ,461 & ,81996 \\
\hline
\end{tabular}

Sumber: Hasil Output SPSS 25, data diolah peneliti (2019) 
Berdasarkan tabel 3, Adjusted $R$ Square menunjukkan nilai sebesar 0,461 atau 46,1\%> Hal ini berarti kemampuan seluruh variabel bebas yakni likuiditas leverage dan profitabilitas terhadap return saham sebesar 46,1\%. Sisanya 53,9\% dijelaskan oleh variabel lain di luar penelitian.

\section{Uji Moderated Regression Analysis (MRA)}

Tabel 4. Uji MRA Pengaruh Nilai Tukar (Kurs) dalam Memoderasi Hubungan Antara Variabel Rasio Likuiditas yang Diukur dengan CR Terhadap Return Saham

\begin{tabular}{|c|c|c|c|c|c|c|}
\hline \multicolumn{7}{|c|}{ Coefficients $^{\mathrm{a}}$} \\
\hline & & \multicolumn{2}{|c|}{$\begin{array}{c}\text { Unstandardized } \\
\text { Coefficients }\end{array}$} & $\begin{array}{c}\text { Standardized } \\
\text { Coefficients }\end{array}$ & \multirow[b]{2}{*}{$\mathrm{t}$} & \multirow[b]{2}{*}{ Sig. } \\
\hline \multicolumn{2}{|c|}{ Model } & $\mathrm{B}$ & Std. Error & Beta & & \\
\hline & (Constant) & $-13,867$ & 2,976 & & $-4,660$ &, 000 \\
\hline & $\mathrm{CR}$ & ,024 & ,165 & 025 & ,143 &, 887 \\
\hline & Kurs &, 001 &, 000 & ,734 & 4,544 &, 000 \\
\hline & $\mathrm{CR} * \mathrm{~K}$ & $-4,013 \mathrm{E}-7$ &, 000 &,- 006 &,- 045 & ,964 \\
\hline
\end{tabular}

a. Dependent Variable: Return saham (y)

Sumber: Hasil Output SPSS 25, data diolah peneliti (2019)

Dari tabel 4 diketahui bahwa nilai tukar (kurs) tidak mampu memoderasi hubungan antara variabel rasio likuiditas yang diukur dengan CR terhadap return saham. Dapat dilihat dari nilai signifikansi yang lebih besar dari $\alpha(0,964>0,05)$. Namun, nilai tukar (kurs) berhubungan dengan variabel dependen (return saham). Hal ini ditunjukkan dengan nilai signifikansi yang lebih kecil dari $\alpha(0,000<0,05)$. Maka dalam hal ini, nilai tukar (kurs) bukanlah variabel moderasi, melainkan variabel prediktor.

Tabel 5. Uji MRA Pengaruh Nilai Tukar (Kurs) Dalam Memoderasi Hubungan Antara Variabel Rasio Leverage Yang Diukur Dengan DER Terhadap Return Saham

\begin{tabular}{|c|c|c|c|c|c|c|}
\hline \multicolumn{7}{|c|}{ Coefficients $^{\mathrm{a}}$} \\
\hline & & \multicolumn{2}{|c|}{$\begin{array}{c}\text { Unstandardized } \\
\text { Coefficients }\end{array}$} & $\begin{array}{c}\text { Standardized } \\
\text { Coefficients }\end{array}$ & \multirow[b]{2}{*}{$\mathrm{t}$} & \multirow[b]{2}{*}{ Sig. } \\
\hline \multicolumn{2}{|c|}{ Model } & $\mathrm{B}$ & Std. Error & Beta & & \\
\hline & (Constant) & $-10,396$ & 2,645 & & $-3,931$ &, 000 \\
\hline & DER & $-4,064$ & 1,589 &,- 854 & $-2,557$ & ,016 \\
\hline & Kurs &, 001 & ,000 & ,563 & 4,269 & ,000 \\
\hline & $\mathrm{DER}^{*} \mathrm{~K}$ & ,000 & ,000 &, 717 & 2,300 & 028 \\
\hline
\end{tabular}

a. Dependent Variable: Return saham (y)

Sumber: Hasil Output SPSS 25, data diolah peneliti (2019)

Dari tabel diatas diketahui bahwa nilai tukar (kurs) tidak mampu memoderasi hubungan antara variabel rasio leverage yang diukur dengan DER terhadap return saham. Dapat dilihat dari nilai signifikansi yang lebih kecil dari $\alpha(0,028<0,05)$. Selain itu, nilai tukar (kurs) juga berhubungan dengan variabel dependen (return 
saham). Hal ini ditunjukkan dengan nilai signifikansi yang lebih kecil dari $\alpha$ $(0,000<0,05)$. Maka dalam hal ini, nilai tukar (kurs) merupakan variabel quasi moderator, yakni variabel yang bertindak sebagai moderasi dan pada saat yang bersamaan bertindak pula sebagai variabel independen.

Tabel 6. Uji MRA Pengaruh Nilai Tukar (Kurs) Dalam Memoderasi Hubungan Antara Variabel Rasio Profitabilitas Yang Diukur Dengan ROA Terhadap Return Saham

\begin{tabular}{|c|c|c|c|c|c|c|}
\hline \multicolumn{7}{|c|}{ Coefficients $^{\mathrm{a}}$} \\
\hline & & \multicolumn{2}{|c|}{$\begin{array}{l}\text { Unstandardized } \\
\text { Coefficients }\end{array}$} & $\begin{array}{l}\text { Standardized } \\
\text { Coefficients }\end{array}$ & \multirow[b]{2}{*}{$\mathrm{t}$} & \multirow[b]{2}{*}{ Sig. } \\
\hline \multicolumn{2}{|c|}{ Model } & B & Std. Error & Beta & & \\
\hline & (Constant) & -13.299 & 2.538 & & -5.241 & .000 \\
\hline & ROA & 3.778 & 9.744 & .437 & .388 & .701 \\
\hline & Kurs & .001 & .000 & .688 & 5.230 & .000 \\
\hline & $\mathrm{ROA}^{*} \mathrm{~K}$ & $-8.735 \mathrm{E}-5$ & .001 & -.132 & -.115 & .909 \\
\hline
\end{tabular}

a. Dependent Variable: Return saham (y)

Sumber: Hasil Output SPSS 25, data diolah peneliti (2019)

Dari hasil analisis diatas diketahui bahwa nilai tukar (kurs) tidak mampu memoderasi hubungan antara variabel rasio profitabilitas yang diukur dengan ROA terhadap return saham. Dapat dilihat dari nilai signifikansi yang lebih besar dari $\alpha(0,909>0,05)$. Namun, nilai tukar (kurs) berhubungan dengan variabel dependen (return saham). Hal ini ditunjukkan dengan nilai signifikansi yang lebih kecil dari $\alpha(0,000<0,05)$. Maka dalam hal ini, nilai tukar (kurs) bukanlah variabel moderasi, melainkan variabel prediktor.

\section{Pembahasan}

Rasio likuiditas dengan menggunanakan alat ukur current ratio (CR) secara parsial memiliki pengaruh positif dan signifikan terhadap return. Semakin tinggi current ratio berarti semakin besar kemampuan perusahaan dalam membayar hutang. Hasil yang positif menunjukkan bahwa setiap kenaikan current ratio akan meningkatkan return saham. Hal ini disebabkan bahwa jika semakin baik current ratio mencerminkan semakin likuid perusahaan tersebut, sehingga kemampuan perusahaan untuk memenuhi kemampuan jangka pendeknya semakin tinggi, sehingga akan mampu meningkatkan return saham perusahaan. Hasil ini konsisten dengan hasil penelitian yang dilakukan oleh Surya, dkk (2010), Safitri, dkk (2015), dan Putra \& Dana (2016) yang membuktikan bahwa current ratio (CR) berpengaruh positif dan signifikan terhadap return saham.

Rasio leverage dengan menggunanakan alat ukur debt to equity ratio (DER) memiliki pengaruh negatif dan signifikan terhadap return saham. Hasil penelitian ini mengindikasikan bahwa apabila DER semakin tinggi maka akan berbanding terbalik terhadap return yang akan 
diterima oleh investor. Hasil penelitian ini juga sesuai dengan hasil penelitian yang dilakukan oleh Surya, dkk (2010), Farkhan \& Ika (2013), Putra \& Dana (2016), Kurniawan (2017), dan Syahbani, dkk (2018) yang menyatakan bahwa nilai DER memiliki pengaruh yang negatif dan signifikan terhadap return saham.

Rasio profitabilitas dengan menggunanakan alat ukur Return on Assets (ROA) secara parsial memiliki pengaruh positif dan signifikan terhadap return saham. Hasil yang positif menunjukkan bahwa kinerja perusahaan yang semakin baik dan efisien dalam memanfaatkan aktivanya sehingga memperoleh laba yang tinggi. Laba yang tinggi akan menyebabkan permintaan atas saham semakin meningkat sehingga harga saham akan naik yang mengakibatkan return yang diperoleh investor juga meningkat. Hasil ini sesuiai dengan hasil penelitian yang dilakukan oleh Anisa (2015), Putra \& Dana (2016), dan Sorongan (2016) yang membuktikan bahwa Return on Assets (ROA) berpengaruh positif dan signifikan terhadap return saham.

Penelitian menunjukkan bahwa current ratio, debt to equity ratio, dan Return on Asset secara simultan memiliki pengaruh yang signifikan terhadap return saham pada perusahaan farmasi yang terdaftar di Bursa Efek Indonesia pada tahun 2013-2017 maka $\mathrm{H}_{4}$ diterima. Hasil penelitian ini juga sesuai dengan hasil penelitian yang dilakukan oleh Farkhan \& Ika (2013), Erari (2014), dan Sugiarti (2015) menunjukkan bahwa terdapat pengaruh secara simultan dari Current Ratio (CR), Return on Asset (ROA), dan DER (Debt to Equity Ratio) terhadap return saham.

Uji Moderated Regression Analysis (MRA) dilakukan untuk menguji hipotesis kelima $\left(\mathrm{H}_{5}\right)$ yang bertujuan untuk menguji apakah nilai tukar (kurs) memoderasi rasio likuiditas, rasio leverage, dan rasio profitabilitas, yang signifikan terhadap return saham.

Pada tabel 4 dapat dijelaskan bahwa hasil analisis dengan menggunakan uji Moderated Regression Analysis (MRA) mendapatkan hasil bahwa nilai tukar (kurs) tidak mampu memoderasi pengaruh rasio likuiditas terhadap return saham. Hal ini dibuktikan dari nilai signifikansi interaksi rasio likuiditas lebih besar dari $\alpha$ yaitu 0,964>0,05. Hal ini menunjukkan bahwa Ho diterima yang artinya nilai tukar (kurs) tidak mampu memoderasi pengaruh rasio likuiditas terhadap return saham. Nilai tukar tidak mampu memoderasi rasio likuiditas dikarenakan, nilai tukar (kurs) merupakan variabel yang berkaitan dengan faktor ekternal perusahaan.

Selanjutnya, pada Tabel 5 juga dapat dijelaskan bahwa hasil analisis dengan menggunakan uji Moderated Regression Analysis (MRA) mendapatkan hasil bahwa nilai 
tukar (kurs) tidak mampu memoderasi pengaruh rasio leverage terhadap return saham. Hasil ini dibuktikan dari nilai signifikansi interaksi rasio leverage lebih kecil dari $\alpha(0,028<0,05)$. Selain itu, nilai tukar (kurs) juga berhubungan dengan variabel dependen (return saham), hal ini ditunjukkan dengan nilai signifikansi yang lebih kecil dari $\alpha(0,000<0,05)$. Maka dalam hal ini, nilai tukar (kurs) merupakan variabel quasi moderator, yakni variabel yang bertindak sebagai moderasi dan pada saat yang bersamaan bertindak pula sebagai variabel independen. Hal ini berarti bahwa Ho diterima yang artinya nilai tukar tidak mampu memoderasi pengaruh rasio leverage terhadap return saham.

Dan juga pada tabel 6 dapat dijelaskan bahwa hasil analisis dengan menggunakan uji Moderated Regression Analysis (MRA) mendapatkan hasil bahwa nilai tukar (kurs) tidak mampu memoderasi pengaruh rasio profitabilitas terhadap return saham. Hal ini dibuktikan dari nilai signifikansi interaksi rasio profitabilitas lebih besar dari $\alpha$ yaitu 0,909>0,05. Hal ini menunjukkan bahwa Ho diterima yang artinya nilai tukar (kurs) tidak mampu memoderasi pengaruh rasio profitabilitas terhadap return saham. Nilai tukar tidak mampu memoderasi rasio profitabilitas dikarenakan, nilai tukar (kurs) merupakan variabel yang berkaitan dengan faktor ekternal perusahaan.

\section{E. KESIMPULAN}

Rasio likuiditas yang diukur dengan menggunakan Current Ratio (CR) dan rasio profitabilitas yang diukur dengan menggunakan Return on Assets (ROA) berpengaruh positif dan signifikan terhadap return saham pada perusahaan sub sektor farmasi yang terdaftar di BEI tahun 2013-2017. Sedangkan Rasio leverage yang diukur dengan menggunakan Debt To Equity Ratio (DER) berpengaruh negatif dan signifikan terhadap return saham pada perusahaan sub sektor farmasi yang terdaftar di BEI tahun 2013-2017. Kinerja keungan yang diukur Current Ratio (CR), Debt to Equity Ratio (DER) dan Return on Asset (ROA), secara simultan berpengaruh positif terhadap return saham pada perusahaan sub sektor farmasi yang terdaftar di BEI tahun 2013-2017. Nilai tukar (kurs) tidak mampu memoderasi hubungan antara rasio likuiditas, rasio leverage dan rasio profitabilitas terhadap return saham.

\section{Saran}

Bagi investor sebelum menanamkan modal, sebaiknya menganalisis kondisi rasio likuiditas, rasio leverage dan rasio profitabilitas. Selain pentingnya menganalisis bagaimana prospek industri perusahaan tersebut di masa yang akan datang, diharapkan investor juga memperhatikan faktor-faktor eksternal yang berpengaruh terhadap kinerja perusahaan 
misalnya seperti keadaan ekonomi global di luar perusahaan. Hal ini dimaksudkan agar nantinya modal yang ditanamkan menghasilkan return yang suistanable (berkelanjutan). Bagi peneliti selanjutnya sebaiknya melakukan penelitian dengan periode lebih lama untuk mendapatkan hasil yang lebih baik dari penelitian ini. Selain itu, peneliti juga bisa menggunakan indikator lebih dari satu dalam setiap variabel penelitian.

\section{DAFTAR PUSTAKA}

Afiyati, H. T., \& Topowijono, (2018). Pengaruh Inflasi, BI Rate Dan Nilai Tukar Terhadap Return Saham (Studi Pada Perusahaan Subsektor Food \& Beverages Yang Terdaftar Di Bursa Efek Indonesia Periode 2013-2016). Jurnal Administrasi Bisnis (JAB), 61(2), 144-151.

Anisa, N. (2015). Analisis Faktor-Faktor Yang Mempengaruhi Return Saham (Studi Kasus Pada Perusahaan Sub Sektor Automotive And Components Yang Terdaftar Di Bursa Efek Indonesia Periode 2010-2014). Perbanas Review, 1(1), 72-86.

Ekananda, M. (2014). Ekonomi Internasional. Jakarta: Erlangga.

Erari, A. (2014). Analisis Pengaruh Current Ratio, Debt To Equity Ratio, dan Return on Asset Terhadap Return Saham Pada Perusahaan Pertambangan di Bursa Efek Indonesia. Jurnal Manajemen \& Bisnis, 5(2), 174-191.

Fahmi, I. (2012). Analisis Laporan Keuangan. Cetakan Ke-2, Bandung: Alfabeta.

Fahmi, I. (2014). Manajeman Keuangan Perusahaan Dan Pasar Modal (Edisi pertama ed.). Jakarta: Mitra Wacana Media.

Farkhan, \& Ika. (2013). Pengaruh Rasio Keuangan Terhadap Return Saham Perusahaan Manufaktur Di Bursa Efek Indonesia (Studi kasus Pada Perusahaan Manufaktur Sektor Food And Beverage). VALUE ADDED, 9(1)

Hanafi, M. (2015). Manajemen keuangan (Edisi pertama ed.). Yogyakarta: BPFE Yogyakarta.

Hartono, J. (2014). Teori Portofolio dan Analisis Investasi. Yogyakarta: BPFE Yogyakarta.

http://www.kompas.com/ diakses 2 Maret 2019

http://www.kompas.com/ diakses 2 Maret 2019

Kurniawan, A. (2017). Pengaruh Kinerja Keuangan Terhadap Return Saham Dengan Menjadikan Kebijakan Dividen Sebagai Variabel Moderate Pada Perusahaan Yang Terdaftar Di Jakarta Islamic Indeks ( JII 2007 - 2011). AKUISISI, 13(1).

Murhadi, W. R. (2013). Analisis Laporan Keuangan, Proyeksi dan Valuasi Saham. Jakarta: Salemba Empat.

Nidianti, P. I. (2013). Pengaruh Faktor Internal Dan Eksternal Perusahaan Terhadap Return Saham Food And Beverages Di Bursa Efek Indonesia. E-Jurnal Akuntansi Universitas Udayana, 5(1), 130-146.

Pujawati, P. E., Wiksuana, I., \& Artini, L. (2015). Pengaruh Nilai Tukar Rupiah Terhadap Return Saham. E-Jurnal Ekonomi dan Bisnis Universitas Udayana, 4(4), 220-242. 
Putra, I. M., \& Dana, I. (2016). Pengaruh Profitabilitas, Leverage, Likuiditas Dan Ukuran Perusahaan Terhadap Return Saham Perusahaan Farmasi Di BEI. E-Jurnal Manajemen Unud, 5(11), 68256850 .

Safitri, O., Sinarwati, \& Atmadja , A. (2015). Analisis Pengaruh Profitabilitas, Likuiditas, Dan Leverage Terhadap Return Saham Pada Perusahaan Manufaktur Yang Terdaftar Di BEI Tahun 2009-2013. e-Journal S1 Ak Universitas Pendidikan Ganesha, 3(1).

Sorongan, F. A. (2016). Factors Affecting The Return Stock Company In Indonesia Stock Exchange (IDX) LQ45 In Years 2012-2015. Journal The WINNERS, 17(1), 37-45,

Sugiarti, Surachman , \& Aisjah, S. (2015). Pengaruh Kinerja Keuangan Perusahaan terhadap Return Saham (Studi pada Perusahaan Manufaktur yang Terdaftar di Bursa Efek Indonesia). Jurnal Aplikasi Manajemen (JAM), 13(2), 282-297.

Surya, R., Agusti, R., \& Asnel, Y. (2010). Analisis Pengaruh Rasio Likuiditas, Leverage, Aktivitas dan Profitabilitas Terhadap Return Saham Pda Perusahaan Consumer Goods Yang Terdaftar Di BEI. Jurnal Kajian Akuntansi dan Auditing, 5(1).

Syahbani, D. I., Murni, Y., \& Fredy, H. (2018). Analisis Pengaruh Rasio Likuiditas, Leverage Dan Profitabilitas Terhadap Return Saham Pada Perusahaan Makanan Dan Minuman. Jurnal Program Studi Pendidikan Ekonomi, 7(1), 1-6.

Wagiyem. (2013). Analisis Pengaruh Kinerja Keuangan Terhadap Return Saham Pada Perusahaan Manufaktur Yang Terdaftar Di Bursa Efek Indonesia. Riset Manajemen \& Akuntansi, 4(7), 6992. 